\title{
Evaluation of the Bactericidal Activity of Didecyl Dimethyl Ammonium Chloride in 2-Propanol against Pseudomonas aeruginosa Strains with Adaptive Resistance to this Active Substance According to European Standards
}

This study evaluated the bactericidal activity of the cationic surface active compound didecyldimethylammonium chloride in 2-propanol against the two reference strains Pseudomonas aeruginosa and Pseudomonas aeruginosa (tetracycline-resistant) as well as their isolates adapted to this active substance. Individual phases and stages of European Standards which are intended to determine the bactericidal activity of disinfectants in medical areas were used. Disinfection parameters of the tested substance as determined by suspension methods were not sufficient to achieve the required bactericidal reduction in the carrier method for Pseudomonas aeruginosa and all its adapted isolates. Pseudomonas aeruginosa (tetracycline-resistant) and its adapted isolates were more sensitive to the tested active substance when the contact time was extended from 5 to $10 / 15 \mathrm{~min}$. Adaptive resistance of Pseudomonas aeruginosa strains can be abolished by using increased concentrations of the tested substance and/or extended contact time.

Key words: Adaptation, didecyl dimethyl ammonium chloride (DDACP), quaternary ammonium compound (QAC), in-use concentrations, Pseudomonas aeruginosa

Beurteilung der bakteriziden Wirkung von Didecyldimethylammoniumchlorid in 2-Propanol gegen Pseudomonas aeruginosa-Stämme mit adaptiver Resistenz gegen diesen Wirkstoff gemäß europäischer Standards. Diese Studie bewertete die bakterizide Wirkung der kationischen oberflächenaktiven Verbindung Didecyldimethylammoniumchlorid in 2-Propanol gegen die zwei Referenzstämme Pseudomonas aeruginosa und Pseudomonas aeruginosa (Tetracyclin-resistent) sowie ihre an diesen Wirkstoff angepassten Isolate. Es wurden einzelne Phasen und Stufen der Europäischen Normen verwendet, um die bakterizide Wirkung von Desinfektionsmitteln in medizinischen Bereichen zu bestimmen. Die durch Suspensionsmethoden bestimmten Desinfektionsparameter der getesteten Substanz reichten nicht aus, um die erforderliche bakterizide Reduktion in der Trägermethode für Pseudomonas aeruginosa und all seine angepassten Isolate zu erreichen. Pseudomonas aeruginosa (Tetracyclin-resistent) und seine angepassten Isolate waren empfindlicher gegenüber dem getesteten Wirkstoff, wenn die Kontaktzeit von 5

Department of Bacteriology and Biocontamination Control, National Institute of Public Health-National Institute of Hygiene, Warsaw, Poland.

Department of Social Medicine and Public Health, Medical University of Warsaw, Warsaw, Poland. auf 10 bzw. 15 min verlängert wurde. Die adaptive Resistenz von Pseudomonas aeruginosa-Stämmen kann durch Verwendung erhöhter Konzentrationen der getesteten Substanz und/oder verlängerter Kontaktzeit aufgehoben werden.

Stichwörter: Adaption, Didecyldimethylammoniumchlorid (DDACP), quaternäre Ammoniumverbindung (QAC), Anwendungskonzentration, Pseudomonas aeruginosa

\section{Introduction}

The biocidal efficacy of chemical disinfectants is determined according to European Standards which are grouped in phases and stages. There are three stages involving different techniques and conditions for testing the efficacy of disinfectants. Phase 1 includes suspension test methods. In phase 2, there are two stages. The first stage of this phase includes suspension test methods. The second stage consists of carrier test methods. Phase 3 is not as yet used in the evaluation of the biocidal efficacy of disinfectants. Development of methods in this phase will consider the efficacy of disinfectants in their place of use $[1,2]$.

Currently, disinfectants ought to be tested consecutively according to phase 1 and stages 1 and 2 of phase 2 . The requirements depend on the area of disinfectant application. However, biocidal efficacy studies are increasingly being limited to phase 2 , stage 2 . The requirements in this phase and stage are highest, because the bacterial suspension with the interfering substance is fixed to the carrier surface $[1,2]$.

Bactericidal activity is evaluated using reference strains that have a specific resistance to disinfectants. These strains are obligatory in evaluating biocidal efficacy. Additional test strains can be used only when the required reduction of bacteria has been obtained for obligatory strains [2].

The effectiveness of disinfectants depends not only on the type of strain, but also on the concentration and potency of the active ingredients in the formulation and the contact time between the active substance and the bacteria. The presence of inhibitors such as organic matter in the environment of disinfectant application limits the effectiveness of the disinfection $[3,4]$.

Determination of the concentration of a disinfectant of unknown biocidal activity can be based either on the basis 
of methods of MIC (Minimum Inhibitory Concentration)/ MBC (Minimum Bactericidal Concentration), PC (Phenol Coefficient) or standards contained in phase 1 [3, 5, 6]. However, these methods are not used to determine the commercial concentrations of disinfectants (in-use concentrations) because they do not take into account the organic contamination and the attachment of the bacteria to the surface. To determine the commercial concentrations of biocide standards of phase 2 stage 2 ought to be applied. Concentrations of disinfectants determined based on the method of MIC/ MBC, PC or the standards of phase 1 used in the disinfected area may have a static effect on bacteria and lead to their survival on surfaces in the environment [6]. The use of disinfectants at sub-inhibitory concentrations rather than biocidal ones may lead to the acquisition of adaptive resistance by microorganisms and thereby lead to their spread in the environment $[4,7-9]$.

It has been proven that the use of disinfectants in sub-inhibitory concentrations induces resistance mechanisms in (mainly Gram-negative) bacteria such as overexpression of efflux pumps and the production of enzymes degrading disinfectants [8, 10-13]. Also, bacterial modification of fatty acids and phospholipid compositions that build the cell membrane promotes the reduction of sensitivity to disinfectants of planktonic and biofilm cells $[3,7,11]$. This can hinder the combating of such cells and require the use of higher concentrations of active substances [6].

Didecyl dimethyl ammonium chloride (DDAC) is an active substance reducing surface tension which has strong bactericidal action [14]. Consequently, it is widely used for surface disinfection $[9,15]$. At the same time, it is an active substance classified to quaternary ammonium compounds (QACs), to which bacterial resistance was most often ascribed [7, 16, 17].

The aim of the study was to determine the activity of didecyl dimethyl ammonium chloride in 2-propanol against $P$. aeruginosa strains, showing increased insensitivity to this active substance, according to European Standards intended to determine the biocidal activity of disinfectants.

\section{Experimental Procedure}

To evaluate the bactericidal activity of $50 \%$ didecyl dimethyl ammonium chloride in 20\% 2-propanol (DDACP) according to European Standards intended for testing biocidal activity of disinfectants, the following reference strains were used: P. aerugionosa ATCC 15442 (PA) used in the estimation of biocidal efficiency in European Standards (MIC DDACP $45 \mathrm{mg} / \mathrm{L}$ ); $P$. aeruginosa ATCC 47085 (PAO-LAC) a tetracycline-resistant strain ( $\mathrm{MIC}_{\text {DDACP }} 65 \mathrm{mg} / \mathrm{L}$ ); and their isolates obtained after adaptation process to didecyl dimethyl ammonium chloride in 2-propanol. The adaptation process consisted of passing the bacterial suspension to a liquid medium containing increasing concentrations of the tested substance (seven consecutive passages). After adaptation process the isolates were divided into three groups and passaged to solid media: A - unadapted strains, isolated from control of the adaptation process (MIC DDACP $30-35 \mathrm{mg} / \mathrm{L}$ ), passaged onto slant medium without an active substance; $\mathrm{B}$ - strains with adaptive resistance $\left(\mathrm{MIC}_{\mathrm{DDACP}}>375 \mathrm{mg} /\right.$ L) passaged onto slant medium with $375 \mathrm{mg} / \mathrm{L}$ DDACP; and $\mathrm{C}-$ strains with adaptive resistance $\left(\mathrm{MIC}_{\mathrm{DDACP}} 355\right.$ $->375 \mathrm{mg} / \mathrm{L}$ ) passaged onto slant medium without DDACP [18]. Reference strains (PA and PAO-LAC) and isolates of groups A, B, C from the twentieth passage were used for the study of bactericidal efficiency in European Standards. The sensitivity of the abovementioned strains to DDACP was tested according to categories of tests designed for active substances and disinfectants in medical areas, i. e., in phase 1 (PN-EN 1040), in phase 2, stage 1 (PN-EN 13727) and phase 2, stage 2 (PN-EN 14561).

\subsection{Tested concentrations of DDACP}

The activity of DDACP was tested in two concentrations: one in the active range and one in the non-active range. The concentration of DDACP used in PN-EN 1040 (phase 1) in the active range amounted to $89 \mathrm{mg} / \mathrm{L}$ and in the non-active range $42 \mathrm{mg} / \mathrm{L}$. In PN-EN 13727 (phase 2; stage 1) and PNEN 14561 (phase 2; stage 2), the concentrations of DDACP were $1250 \mathrm{mg} / \mathrm{L}$ in the active range and $470 \mathrm{mg} / \mathrm{L}$ in the non-active range.

\subsection{Bacterial cultures}

The stock cultures of P. aeruginosa ATCC 15442 and its isolates were subcultured in Tryptone Soya Agar. Pseudomonas aeruginosa ATCC 47085 (PAO-LAC) and its isolates were subcultured in LB Miller Agar $+10 \mu \mathrm{g} / \mathrm{mL}$ tetracycline. In order to prepare the working cultures of these test organisms, a subculture from the stock cultures was prepared by streaking onto slopes with an appropriate medium. All strains were incubated at $37^{\circ} \mathrm{C}$, except PAO-LAC and its isolates, which were incubated at $30^{\circ} \mathrm{C}$ for $24 \mathrm{~h}$. Two successive subcultures were prepared. The second subcultures were used in methods of the evaluation of bactericidal activity, i.e., PN-EN 1040, PN-EN 13727 and PN-EN 14561.

\subsection{PN-EN 1040}

DDACP was added to a test suspension of the bacteria to be examined. The number of cells of the tested strains in the suspensions was between $1.5 \times 10^{8}$ and $5 \times 10^{8} \mathrm{cfu} / \mathrm{mL}$. The mixture of the test suspension and DDACP at the specified concentrations was maintained at $20^{\circ} \mathrm{C}$ for $5 \mathrm{~min} \pm$ $10 \mathrm{~s}, 10 \mathrm{~min} \pm 10 \mathrm{~s}$ and $15 \mathrm{~min} \pm 10 \mathrm{~s}$. After the contact time, an aliquot was neutralized for $5 \mathrm{~min} \pm 10 \mathrm{~s}$. Two samples of $1 \mathrm{ml}$ were inoculated using the pour plate technique. After $48 \mathrm{~h}$ incubation, in conditions specified for the tested strains, the numbers of surviving bacteria in each sample were determined and the reduction was calculated. DDACP was considered as active if it demonstrated at least a 5 decimal lg reduction [5].

\subsection{PN-EN 13727}

Bactericidal activity of DDACP was tested in clean conditions $(0.3 \mathrm{~g} / \mathrm{L}$ bovine albumin solution) at three contact times $(5 \mathrm{~min} \pm 10 \mathrm{~s}, 10 \mathrm{~min} \pm 10 \mathrm{~s}$ and $15 \mathrm{~min} \pm 10 \mathrm{~s})$. In comparison to the concentrations of DDACP used in PNEN 1040, the concentrations of DDACP were increased about 14 times in the active range and the 11 times in the non-active range. The number of cells in the suspension was obtained in the range required by the standard $\left(1.5 \times 10^{8}\right.$ and $\left.5 \times 10^{8} \mathrm{cfu} / \mathrm{mL}\right)$. A tube with mixtures of the test suspension and the interfering substance were placed in a water bath at $20^{\circ} \mathrm{C}$ for $2 \mathrm{~min} \pm 10 \mathrm{~s}$. After this time, the tested solutions were added for selected contact times. At the end of the contact times, $1 \mathrm{~mL}$ of each sample was transferred to a neutralizer for $10 \mathrm{~s} \pm 1 \mathrm{~s}$ in the case of contact times of 5 and $10 \mathrm{~min}$ and for $5 \mathrm{~min} \pm 10 \mathrm{~s}$ in the case of a 15 -minute contact time. $1 \mathrm{ml}$ samples of the test mixtures in duplicate were inoculated using the pour plate technique. After $48 \mathrm{~h}$ incubation, in conditions specified for the tested 
strains, the numbers of surviving bacteria in each sample were determined and the reduction was calculated. DDACP was considered as active if it demonstrated at least a 5 decimal lg reduction [19].

\subsection{PN-EN 14561}

The test was carried out on glass carriers, on which the test suspension with the interfering substance solution (clean conditions: $0.3 \mathrm{~g} / \mathrm{L}$ bovine albumin solution) was spread. The number of cells in a test suspension ranged from $1.5 \times 10^{9} \mathrm{cfu} / \mathrm{mL}$ to $5 \times 10^{9} \mathrm{cfu} / \mathrm{mL}$. Carrier glasses with test suspensions and interfering substances were dried in a laminar chamber at room temperature for up to $60 \mathrm{~min}$. After drying, each carrier was immersed in a solution of the test substance for a specified contact time (for $5 \mathrm{~min} \pm 10 \mathrm{~s}$, $10 \mathrm{~min} \pm 10 \mathrm{~s}$ and $15 \mathrm{~min} \pm 10 \mathrm{~s}$ ) or in hard water intended to control the recovery of bacteria from the carrier, without the effect of the active substance. After the contact time, the glass carriers were transferred into tubes with a neutralizer and glass beads. After the neutralization time, the bacteria were shaken with glass beads to detach them from the surface of the carrier. In each sample, the number of surviv-

\section{a) Active concentration: $89 \mathrm{mg} / \mathrm{L}$}

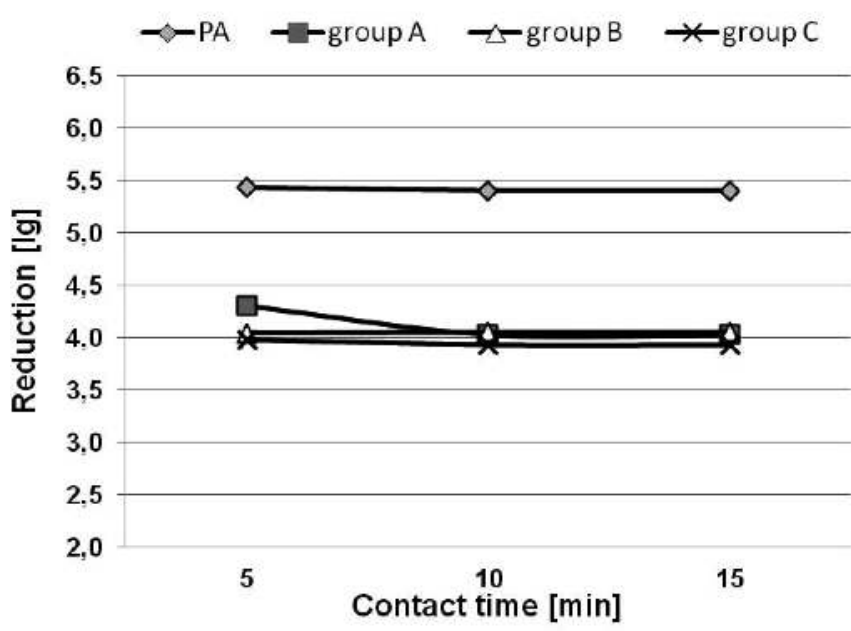

b) Non-active concentration: $42 \mathrm{mg} / \mathrm{L}$

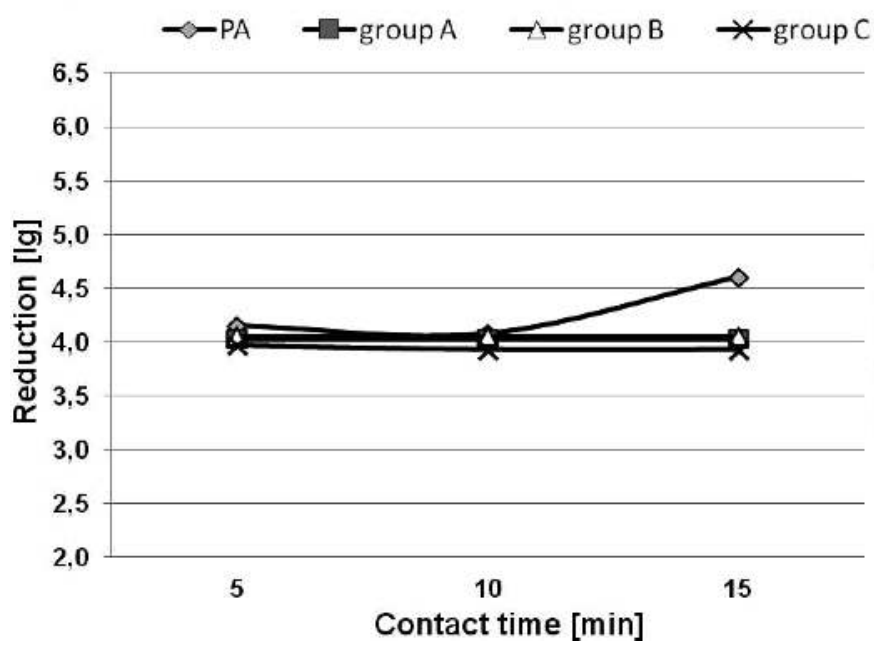

ing bacteria was specified. The reduction was determined by calculating the difference between the number of bacteria recovered from the carrier after hard water treatment and the number of bacteria remaining in the test after DDACP activity and neutralization. DDACP was considered as active if it demonstrated at least a 5 decimal lg reduction [20].

\subsection{Statistical analysis}

Tests were carried out in validated methods in one repetition. The reproducibility standard deviation was determined for each methods [21]. The reproducibility standard deviation for EN 1040 was \pm 0.09 lg; for EN 13727 was $\pm 0.15 \mathrm{lg}$ and for EN 14561 was $\pm 0.05 \mathrm{lg}$.

\section{Results}

\subsection{Phase 1}

PA isolates from groups B and C adapted to DDACP as well as isolates from group A were insensitive to the active concentration of DDACP determined against the reference strain PA. The reduction coefficient for isolates subjected to adapta-

\section{c) Active concentration: $89 \mathrm{mg} / \mathrm{L}$}

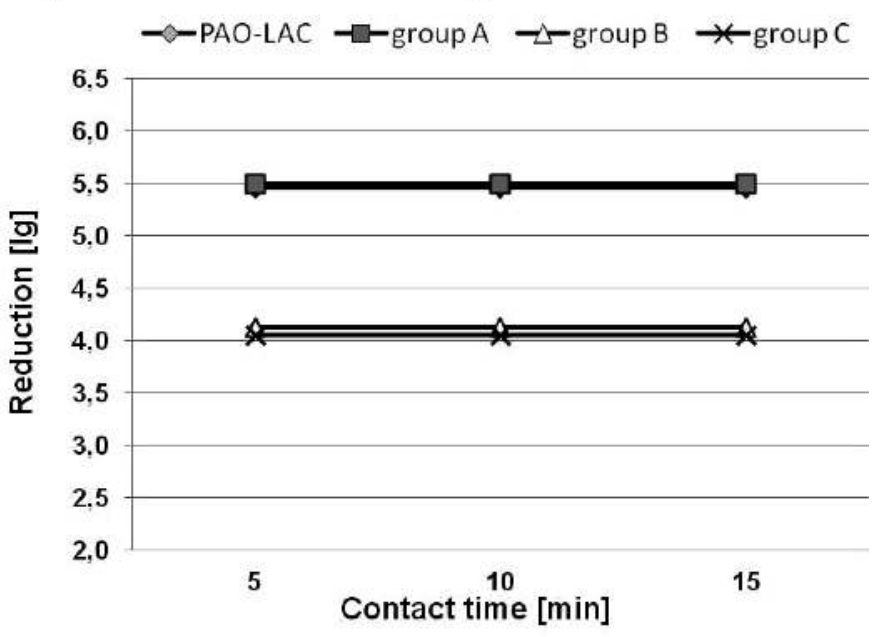

d) Non-active concentration: $42 \mathrm{mg} / \mathrm{L}$

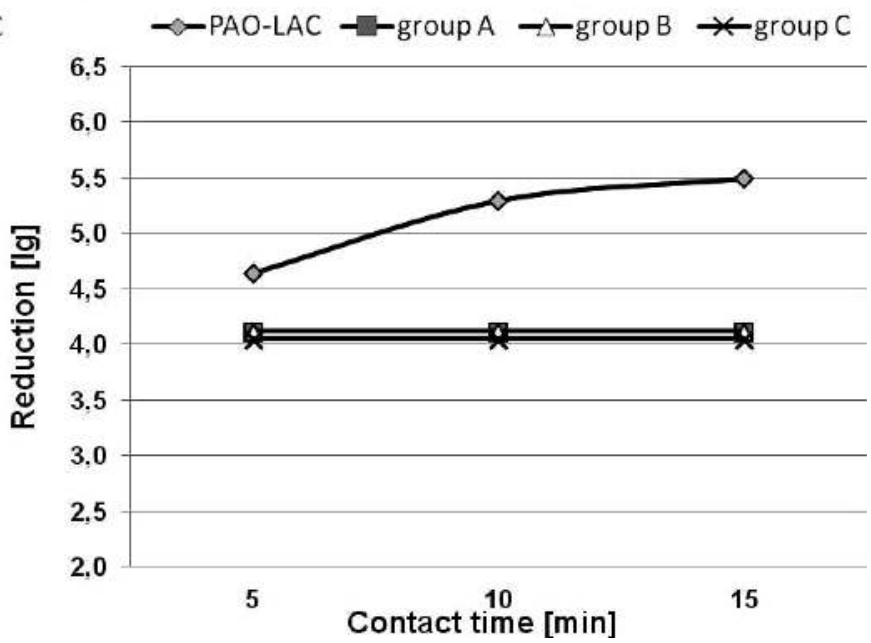

Figure 1 Bactericidal activity of DDACP expressed as reduction $[\mathrm{lg}]$ of the reference strain $P$. aeruginosa ATCC 15442 (PA) and the PA isolates (a; b) and reference strain P. aeruginosa ATCC 47085 (PAO-LAC) and the PAO-LAC isolates (c; d): unadapted (group A) and adapted to DDACP (group B and group C) at active and non-active concentrations and over contact times 5, 10 and 15 min according to PN-EN 1040: 2006. The reproducibility standard deviation of PN-EN 1040: 2006 method was $\pm 0.09 \mathrm{lg}$. 
tion (groups B and C) and the isolates from control group A ranged from 3.93 to 4.05 and this was lower than the required $\lg R=5$ [Fig. 1a]. All tested strains of PA were insensitive to the determined inactive concentration [Fig. 1b].

Tetracycline-resistant strains of PAO-LAC adapted to DDACP from groups $\mathrm{B}$ and $\mathrm{C}$ were insensitive to the tested active concentration (lgR in the range from 4.05 to 4.12 ). The basic bactericidal activity was demonstrated against the reference strain PAO-LAC and against the isolates from control group A [Fig. 1c].

The PAO-LAC reference strain was susceptible to inactive DDACP concentrations in extended contact times of 10 and 15 min [Fig. 1d].

\subsection{Phase 2 stage 1}

The reference strain PA and its isolates from groups A and $\mathrm{B}$ were sensitive to increased DDACP concentrations in both active and non-active concentrations. The only exception were the isolates from group $\mathrm{C}$, for which the applied active concentration fulfilled the requirements of the standard in the range of a $5 \mathrm{lg}$ reduction only within 10 and $15 \mathrm{~min}$ [Fig. 2a)]. Non-active concentrations of DDACP toward PA

\section{a) Active concentration: $1250 \mathrm{mg} / \mathrm{L}$}

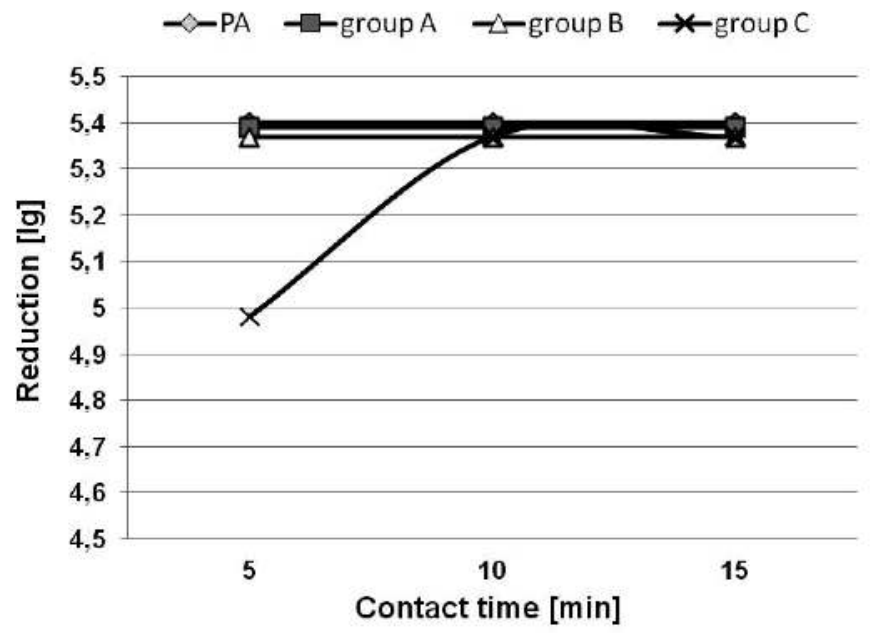

b) Non-active concentration: $470 \mathrm{mg} / \mathrm{L}$

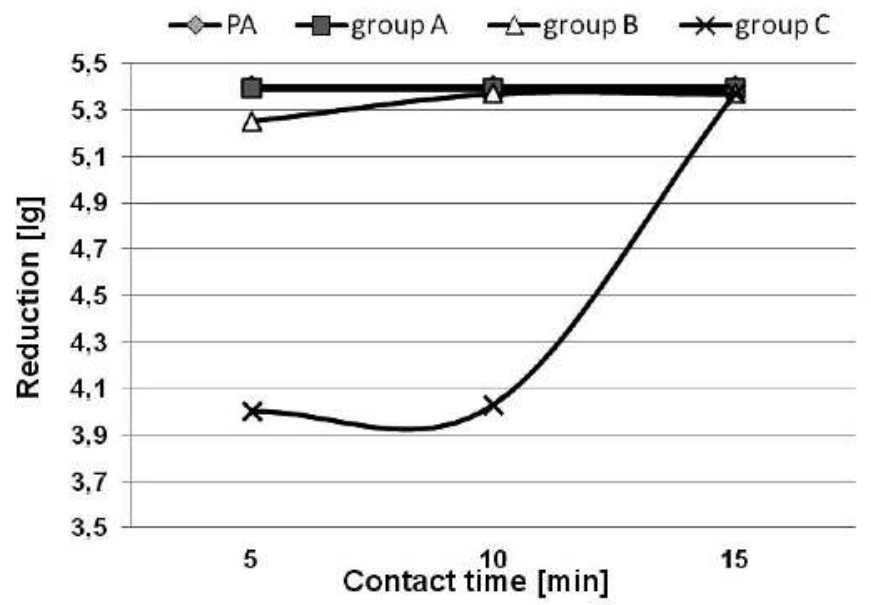

from group $\mathrm{C}$ met the standard assumptions regarding the requirements for inactive concentrations at 5 and $10 \mathrm{~min}$. Over an extended contact time of $15 \mathrm{~min}$, the reduction was as in the case of the determined active concentration [Fig. 2b].

Tetracycline-resistant strain PAO-LAC was sensitive to the tested active and non-active concentrations, both for the reference strain and unadapted isolates from group A subjected only to passage as well as in the case of isolates from groups $\mathrm{B}$ and $\mathrm{C}$ - adapted to DDACP at the contact times of 5, 10 and 15 min [Fig. 2c and 2d].

\subsection{Phase 2 stage 2}

The results obtained in the carrier standard of PN-EN 14561 are in contradiction to results obtained in the suspension standard of PN-EN 13727+A2: 2015-12. There was a lack of activity toward PA and its isolates from groups A and B in the case of the active and non-active concentrations used over the three contact times tested. However, active and non-active concentrations of DDACP were bactericidal against the isolates from group $\mathrm{C}$ at $15 \mathrm{~min}$ contact time [Fig. 3a and 3b].

\section{c) Active concentration: $1250 \mathrm{mg} / \mathrm{L}$}

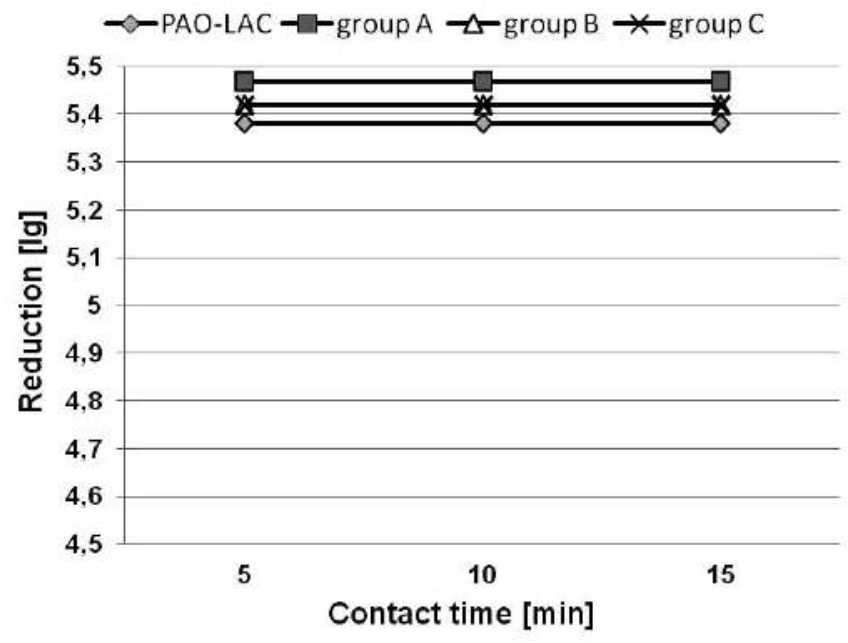

d) Non-active concentration: $\mathbf{4 7 0} \mathrm{mg} / \mathrm{L}$

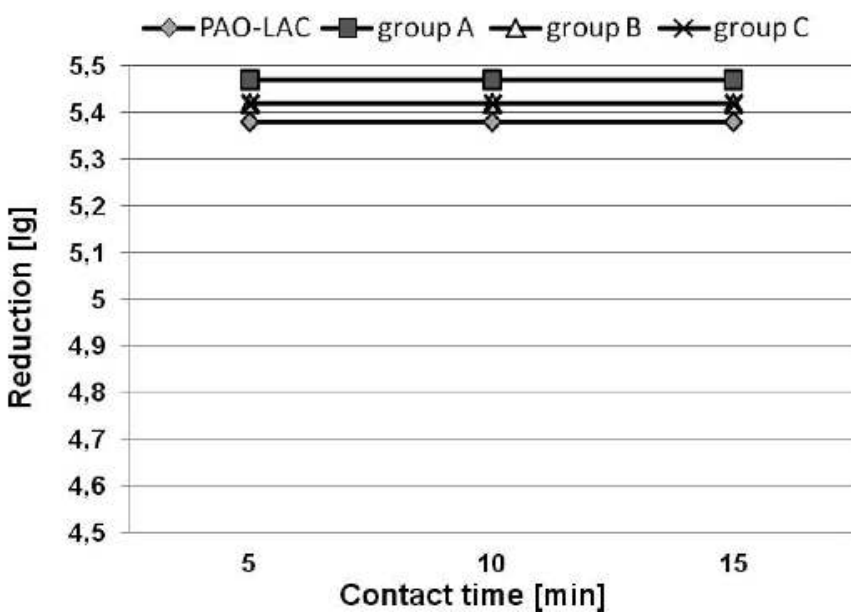

Figure 2 Bactericidal activity of DDACP expressed as reduction $[\mathrm{lg}]$ of the reference strain $P$. aeruginosa ATCC 15442 (PA) and the PA isolates (a; b) and reference strain P. aeruginosa ATCC 47085 (PAO-LAC) and the PAO-LAC isolates (c; d): unadapted (group A) and adapted to DDACP (group B and group C) at active and non-active concentrations over contact times 5, 10 and 15 min according to PN-EN 13727+A2: 2015-12. The reproducibility standard deviation of PNEN 13727+A2: $2015-12$ method was $\pm 0.15 \mathrm{lg}$. 
PAO-LAC was insensitive to the active concentration at a contact time of $5 \mathrm{~min}$ in the case of both the reference strain and isolates from individual groups. The activity of all tested isolates and the reference strain was achieved in extended contact times of 10 and $15 \mathrm{~min}$ at active concentrations [Fig. 3c)].

Similar changes were observed in the case of non-active concentrations, which did not reduce the number of tested microorganisms to the required reduction level within $5 \mathrm{~min}$ and $10 \mathrm{~min}$ of contact against the reference PAOLAC and the isolate from group A, which was passaged without DDACP. At 15 min contact time, the non-active concentration reduced the number of tested microorganisms to an average active level amounting to $>5.40 \mathrm{lg}$ [Fig. 6d].

\section{Discussion}

Exposure of bacteria to the active substances of disinfectants can lead to their adaptation to stressful conditions, especially if the concentrations of active substances are not bactericidal, but only bacteriostatic [6, 12, 16, 22]. Adaptation of $P$. aeruginosa to active substances of disinfectants has been

\section{a) Active concentration: $1250 \mathrm{mg} / \mathrm{L}$}

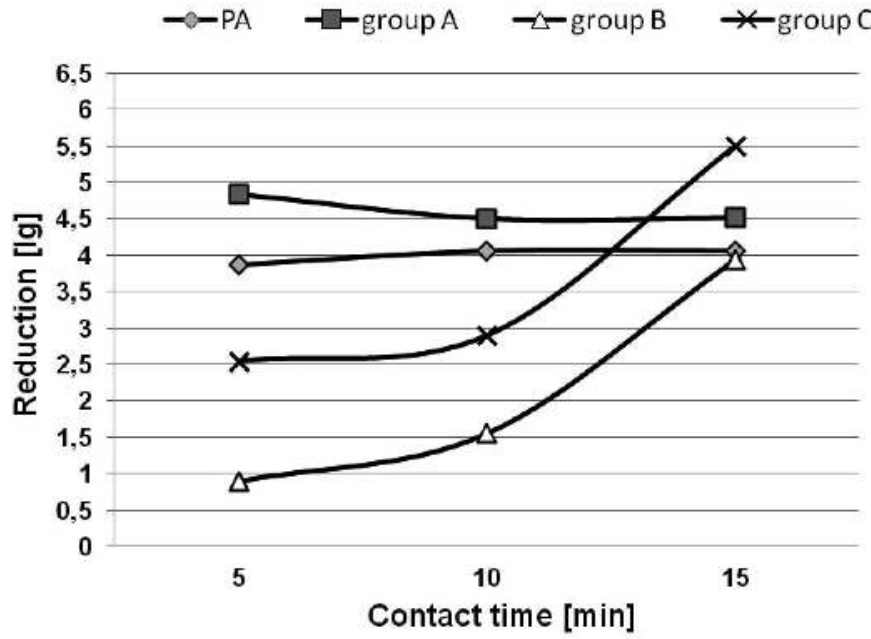

b) Non-active concentration: $470 \mathrm{mg} / \mathrm{L}$

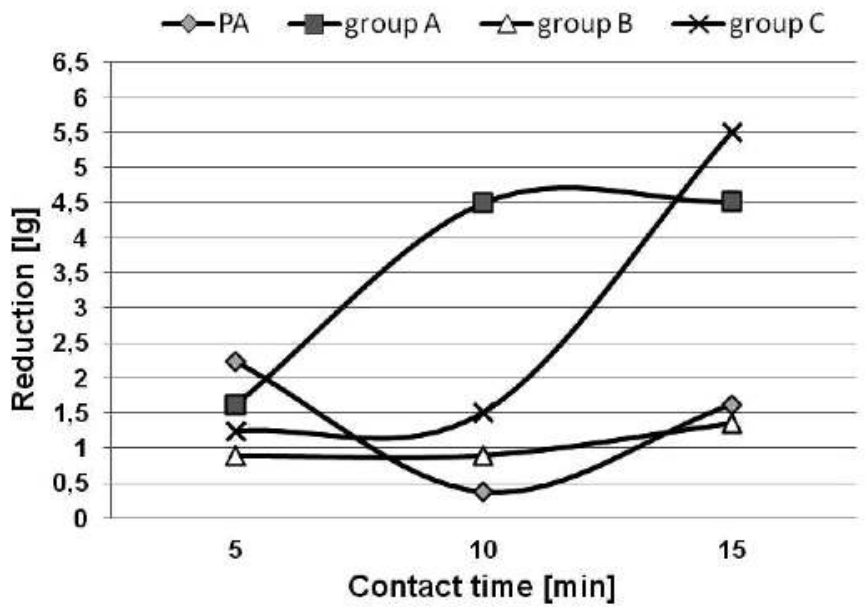

widely described in the literature [10, 16, 22-24]. In the suspension tests of phase 1 , the basic bactericidal action of disinfectants is determined. However, under organic loading conditions, the concentration determined in this phase of the study may be only bacteriostatic. Determination of inuse parameters of disinfectants should take place in conditions most similar to those existing in the area where disinfectants are to be used [1, 2].

This study has illustrated the differences in the activity of didecyl dimethyl ammonium chloride in 2-propanol in the individual phases of testing disinfectants against reference strains of PA and PAO-LAC and their isolates adapted to this active substance (group B; group C) as well as for isolates not adapted but only passages in parallel (group A).

In the suspension test of phase 1 , the active concentration was bactericidal for PA and PAO-LAC reference strains and for group A of strain PAO-LAC. PA isolates from groups A, $\mathrm{B}$ and $\mathrm{C}$ were insensitive to the active concentration, which indicates that the presence of adaptive resistance can come from contact with DDACP (groups B and C) or can be acquired through serial passages (group A) [25].

Groups B and C isolates of PAO-LAC, as opposed to isolate from group $\mathrm{A}$, showed insensitivity to the active concen-

\section{c) Active concentration: $1250 \mathrm{mg} / \mathrm{L}$}

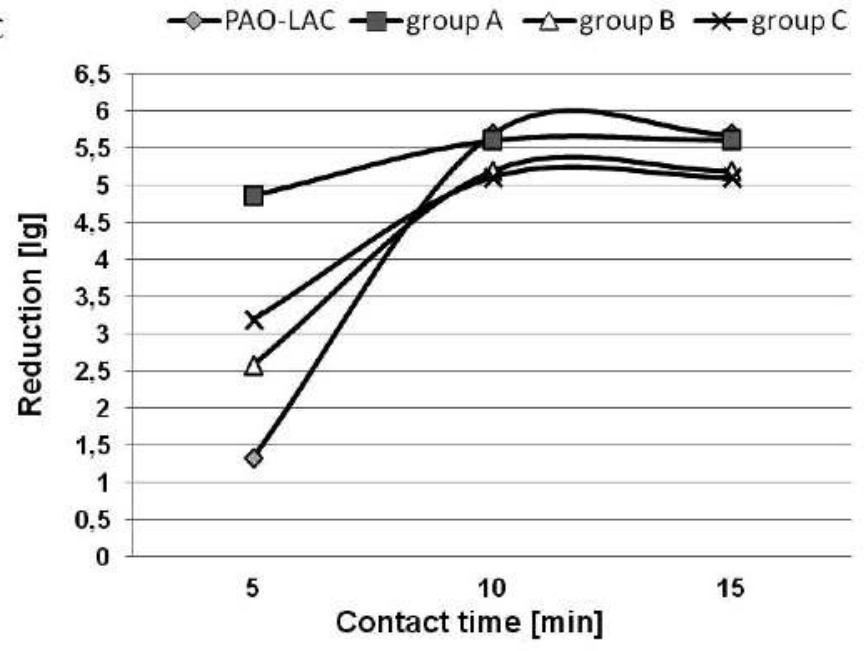

d) Non-active concentration: $470 \mathrm{mg} / \mathrm{L}$

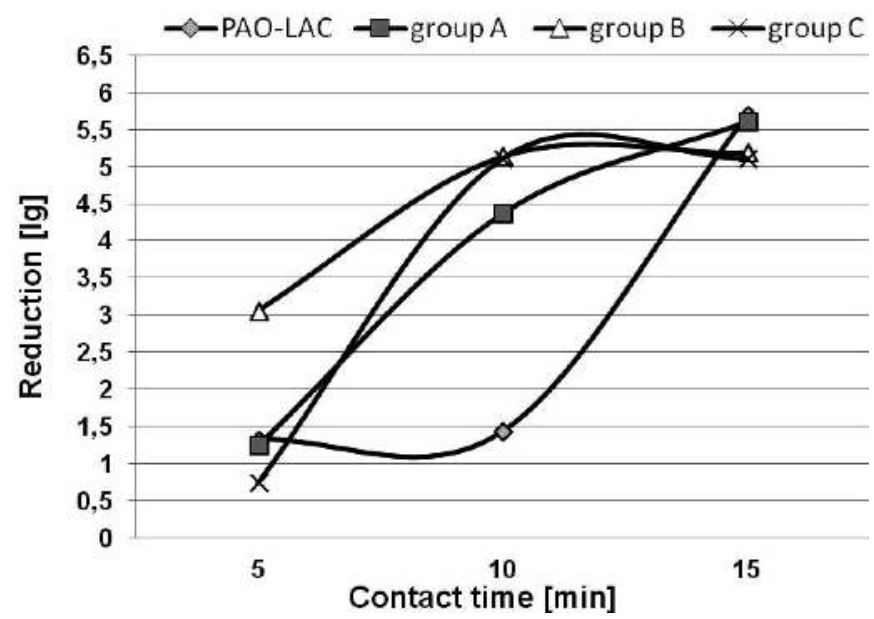

Figure 3 Bactericidal activity of DDACP expressed as reduction $[\mathrm{lg}]$ of the reference strain P. aeruginosa ATCC 15442 (PA) and the PA isolates (a; b) and reference strain P. aeruginosa ATCC 47085 (PAO-LAC) and the PAO-LAC isolates (c; d): unadapted (group A) and adapted to DDACP (group B and group C) at active and non-active concentrations and over contact times 5, 10 and 15 min according to PN-EN 14561: 2008. The reproducibility standard deviation of PN-EN 14561: 2008 method was $\pm 0.05 \mathrm{lg}$. 
tration of DDACP, similar to B and C isolates of PA. Tetracycline-resistant reference strain PAO-LAC was more sensitive to DDACP than the reference strain of PA, because the non-active concentration was already bactericidal against it within 10 and $15 \mathrm{~min}$. In this case, biocide resistance and antibiotic cross-resistance was not examined, but in the literature there are many examples showing that this connection exists, especially for QACs used in food processing environments $[13,15]$. Loughlin et al. observed that the PAO1 strain adapted to benzalkonium chloride possesses increasing resistance to chloramphenicol, which inhibits the protein synthesis, and to membrane-active polymyxin B [7].

In the suspension tests of phase 2 stage 1 , the concentrations of DDACP were increased due to the necessity of the application of organic loading. It is well documented that a heavy organic load requires a greater concentration of cationic active substances such as QACs [15]. An elevated concentration of DDACP resulted in the abolition of the adaptive resistance of PA strains with groups B and A. However, to achieve bactericidal effectiveness of this substance against strains from group $\mathrm{C}$, it was also necessary to extend the contact time to $10-15 \mathrm{~min}$. In practice also the rotation of disinfectants allow avoidance of the development of bacterial adaptation to QACs [3]. In the suspension method, the PAOLAC tetracycline-resistant strain and its isolates were sensitive to the non-active and active DDACP concentrations over all tested contact times. No increased resistance to DDACP was observed because of PAO-LAC resistance to tetracycline, although Bjorland et al. observed that penicillin and tetracycline-resistant Staphylococcus aureus isolates recovered from cows were more tolerant to QACs [26].

In the carrier tests of phase 2 step 2, the DDACP bactericidal activity was varied. The PA strain and its isolates showed insensitivity to the active concentration of DDACP differently than in the suspension test of phase 2 stage 1 . The required reduction value of bactericidal activity was only achieved for group $\mathrm{C}$ of PA strain at 15 min contact time. Unlike our results, the suspension and carrier disinfection tests used by Thomas et al., against $P$. aeruginosa strains which exhibited raised MIC for chlorhexidine diacetate and benzalkonium chloride did not show a greater resistance of these strains as compared to reference strains of $P$. aerugino$s a$ [16]. In our study, the PAO-LAC strain and its isolates were more sensitive to the active concentration of DDACP than the PA strain and its isolates in the suspension and carrier tests. Bactericidal activity against these strains was achieved at active concentrations at contact times of 10 and $15 \mathrm{~min}$ and at $15 \mathrm{~min}$ contact time at non-active concentrations. Increased sensitivity of the tetracycline-resistant strain on DDACP may be associated with greater selective pressure derived from an antibiotic and an active substance and with energy expenditure on metabolic processes, which are responsible for the mechanisms of antibiotic resistance and adaptation [27].

The obtained results showed that it is possible to abolish adaptive resistance by increasing the concentration of the tested active substance and extending the contact time. However, the differentiation of DDACP bactericidal activity was not only due to the adaptive resistance of microorganisms to the tested active substance, but also to the test conditions used [12]. The attachment of microorganisms to carriers in phase 2 of stage 2 influenced the change in the bactericidal activity of the tested active substance compared to the activity achieved in phase 2 of stage 1 . There are some reports of changes in the sensitivity of strains attached to the surface, whether culture medium, carrier or biofilm $[9,28$, 29]. Brill et al. indicated that culturing S. aureus and P. aeru- ginosa on solid medium influenced the sensitivity of these strains to cationic active compounds such as benzalkonium chloride, chlorohexidine digluconate and octenidine dihydrochloride. In suspension tests, both organisms grown on agar medium were more sensitive to all tested biocides than cells grown in broth [28]. In contrast, bacteria attached to the surface, e.g., in biofilm, are more difficult to combat and this requires the use of higher concentrations of active substances and/or longer contact times [9, 11, 15, 29]. Gerba postulated that a higher temperature also increased the activity of QACs [15].

Kampf postulates that the high MIC values obtained for benzalkonium chloride against environmental bacteria, including $P$. aeruginosa, may mean that the parameters of disinfectants determined against reference strains may be ineffective in practice [22].

The conducted research indicates the necessity of using carrier methods in determining the in-use parameters of using disinfectants, as suspension methods may not be sufficient to determine the correct disinfection parameters and combat adaptive resistance.

\section{Conclusions}

1. The Pseudomonas aeruginosa strains and their adapted isolates were found to be less sensitive to didecyl dimethyl ammonium chloride in 2-propanol in the carrier method than in the suspension method.

2. Adaptive resistance of Pseudomonas strains can affect the efficiency of surface disinfection if DDACP sub-inhibitory concentrations are used.

3. Correctly determined in-use parameters, i. e., the concentration and contact time of the disinfectant in the carrier methods (phase 2, step 2), can contribute to the abolition of adaptive resistance among Pseudomonas strains.

4. Reference strain Pseudomonas aeruginosa intended to examine the activity of disinfectants in European Standards should be chosen by manufacturers as obligatory strain for determination disinfection parameters.

5. Strains with antibiotics-resistant features, e.g. tetracycline-resistant Pseudomonas aeruginosa, should only be tested as an addition because they can have higher sensitivity and the designated disinfection parameters may be too low to act as bactericidal.

\section{References}

. Gebel, J., Exner, M., French, G., Chartier, Y., Christiansen, B., Gemein, S., Goroncy-Bermes, P., Hartemann, P., Heudorf, U., Kramer, A., Maillard, J.-Y., Olt-

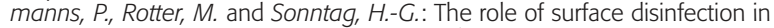
infection prevention, GMS Hyg Infect Control 8 (2013) 1 - 12. DOl: $10.3205 / \mathrm{dgkh000210}$

2. PN-EN 14885: 2015-10. Chemical disinfectants and antiseptics. Application of European Standards for chemical disinfectants and antiseptics.

3. Lungsrud, S., Sundheim, G. and Borgmann-Strahsen, R.: Intranistic acquired resistance to quternary ammonium compounds in food- related Pseudomonas spp, J App Microbiol 95 (2003) 874-882. PMid:12969304; DOI:10.1046/j.1365-2672.2003.02064.x

4. Gadea, R. Fernández Fuentes, M. Á. Pérez Pulido, R. Gálvez, A. and Ortega, E.: Adaptative tolerance to phenolic biocides in bacteria from organic foods: Effect on antimicrobial susceptibility and tolerance to physical stresses, Food Res International 85 (2016); 131 - 143. PMid:29544828; DOI:10.1016/j.foodres.2016.04.033

5. PN-EN 1040: 2006. Chemical disinfectants and antiseptics. Quantitative suspension test for the evaluation of basic bactericidal activity of chemical disinfectants and antiseptics. Test method and requirements (phase 1).

6. Maillard, J. Y.: Bacterial resistance to biocides in the healthcare environment: should it be of genuine concern? J Hosp Infect 65 (2007) 60-72. DOI: 10.1016/S0195-6701(07)60018-8

7. Loughlin, M. F., Jones, M. V. and Lambert, P. A.: Pseudomonas aeruginosa cells adapted to benzalkonium chloride show resistance to other membrane-active agents but not to clinically relevant antibiotics, J Antimicrob Chemother 49 (2002) 631 -639. PMid:11909837; DOI:10.1093/jac/49.4.631 
8. Morita, Y., Tomida, J. and Kawamura, Y.: Responses of Pseudomonas aeruginosa to antimicroabials, Font Microbol 4 (2014) 422. PMid:24409175; DOI:10.3389/fmicb.2013.00422

9. Tezel, U. and Pavlostathis, S. G.: Quaternary ammonium disinfectants: microbial adaptation, degradation and ecology, Current Opinion in Biotechnol. 33 (2015) 296-304. PMid:25864173; DOI:10.1016/j.copbio.2015.03.018

10. Abdel Malek, S. M. A., AL-Adham, I. S. I., Matalka, K. Z. and Collier, P. J.: Pseudomonas aeruginosa $\mathrm{PAO} 1$ resistance to zinc pyrithione: phenotypic changes suggest the involvement of efflux pumps, Curr Microbiol 59 (2009) 95- 100. PMid: 19452215: DOl:10.1007/s00284-009-9396-9

11. Bridier, A., Briandet, R., Thomas, V. and Dubois-Brissonnet, F.: Resistance of biofilms to disinfectants: a review, Biofouling 27 (2011) 1017- 1032 PMid:22011093; DOI:10.1080/08927014.2011.626899

12. McCay, P. H., Oscampo-Sosa, A. A., and Fleming, G. T.: Effect of subinhibitory concentration of benzalkonium chloride on competitiveness of Pseudomonas aeruginosa grown in continuous culture, Microbiol 151 (2010) 30-38. PMid:19815578; DOl:10.1099/mic.0.029751-0

13. Ortega Morente, E., Fernández-Fuentes, M. A., Grande Burgos, M. J., Abriouel, $H .$, Pérez Pulido, $R$. and Gálvez, A.: Biocide tolerance in bacteria, International J Food Microbiol 162 (2013) 13-25. PMid:23340387; DOI:10.1016/j.ijfoodmicro.2012.12.028

14. Nishihara, T., Okamoto, T. and Nishiyama, N.: Biodegradation of Didecyldimethylammonium chloride by Pseudomonas fluorescens TN4 isolated from activated sludge, J Appl Microbiol 88 (2000) 641 -647. PMid: 10792522; DOI: 10.1046/j.1365-2672.2000.01007.x

15. Gerba, Ch. P.: Quaternary Ammonium Biocides: Efficacy in Application, App Environ Microbiol 51 (2015) 464-469. PMid:25362069; DOI:10.1128/AEM.02633-14

16. Thomas, L., Russell, A. D. and Maillard, J. Y.: Antimicrobial activity of chlorhexidine diacetate and benzalkonium chloride against Pseudomonas aeruginosa and its response to biocide residues, J App Microbiol. 98 (2005) 533-543. PMid:15715855; DOI:10.1111/j.1365-2672.2004.02402.x

17. Gadea, R., Fernández Fuentes, M. Á., Pérez Pulido, R., Gálvez, A. and Ortega, $E .:$ Effect of exposure to quaternary-ammonium-based biocides on antimicrobial susceptibility and tolerance physical stresses in bacteria from organic foods, Food Microbiol 63 (2017) 58-71. PMid:28040182; DOI:10.1016/j.fm.2016.10.037

18. Chojecka, A., Wiercińska, O., Röhm-Rodowald, E., Kanclerski K. and Jakimiak, B.: Effect of adaptation process of Pseudomonas aeruginosa to didecyldimetylammonium chloride in 2-propanol on bactericidal efficiency of this active substance. Rocz Panstw Zakl Hig 65 (2014) 359-364.

19. PN-EN 13727+A2: 2015-12. Chemical disinfectants and antiseptics. Quantitative suspension test for the evaluation of bactericidal activity in medical area. Test method and requirements (phase 2 , stage 1).

20. PN-EN 14561: 2008. Chemical disinfectants and antiseptics. Quantitative carrier test for the evaluation of bactericidal activity for instruments used in the medical area. Test method and requirements (phase 2, stage 2)

21. ISO/TS 19036: 2011. Microbiology of food and animal feeding stuffs. Guidelines for the estimation of measurement uncertainty for quantitative determinations.

22. Kampf, G.: Adaptative microbial response to low level benzalkonium chloride exposure, J Hosp Infect 18 (2018) 30284-6. DOI:10.1016/i.jhin.2018.05.019

23. Abdel Malek, S. M. A. AL-Adham, I. S. I. Winder, C. L. Buultjens, T. E. J., Gartland, K.M.A. and Collier, P. J.: Antimicrobial susceptibility changes and T-OMP shifts in pyrithione-passaged planctonic cultures of Pseudomonas aeruginosa PAO1, J Appl Microbiol 92 (2002) 729-736. PMid:11966914 DOI: $10.1046 / j .1365-2672.2002 .01575 . x$

24. Abdel Malek, S. M. A. and Badran, Y. R.: Pseudomonas aeruginosa PAO1 adapted to 2-phenoxyethanol shows cross-resistance to dissimilar biocides and increased susceptibility to antibiotics, Folia Microbiol 55 (2010) 588-592. PMid:21253903: DOl:10.1007/s12223-010-0094-6

25. Martínez, J. L., Baquero, F. and Andersson, D. I.: Beyond serial passages: new methods for predicting the emergence of resistance to novel antibiotics, Curr Opin in Pharmacol 11 (2011) 439-445. PMid:21835695; DOI:10.1016/j.coph.2011.07.005
26. Bjorland, J., Sunde, M. and Waage, S.: Plasmid-borne smr gene causes resistance to quaternary ammonium compounds in bovine Staphylococcus aureus, J Clin Microbiol 39 (2001) 3999-4004. PMid:11682521 DOI:10.1128/JCM.39.11.3999-4004.2001

27. Munita J. M. and Arias C. A.: Mechanisms of antibiotic resistance. Microbiol Spectr 4 (2016) 1-37. DOI: 10.1128/microbiolspec.VMBF-0016-2015

28. Brill, F., Goroncy-Bermes, P. and Sand, W.: Influence of growth media on the sensitivity of Staphylococcus aureus and Peseudomonas aeruginosa to cationic biocides, Int J Hyg Environ Health. 209 (2006) 89-95. PMid: 16373206 ; DOI:10.1016/j.jijheh.2005.08.007

29. Giaouris, E., Chrianpoulos, N., Doulgeraki, A. and Nychas, G. J.: Coculture with Listeria monocytogenes within a dual-species biofilm community strongly increases resistance of Pseudomonas putida to benzalkonium chloride, PLos one 8 (2013) e77276. PMid:24130873; DOI:10.1371/journal.pone.0077276

Received: 17. 12. 2018

Revised: 04. 04. 2019

\section{Bibliography}

DOI 10.3139/113.110632

Tenside Surf. Det.

56 (2019) 4; page 287-293

(c) Carl Hanser Verlag GmbH \& Co. KG

ISSN 0932-3414

\section{Correspondence address}

\section{Dr. Agnieszka Chojecka}

Centrum Kształcenia Kadr Narodowego Instytutu Zdrowia Publicznego -

Państwowego Zakładu Higieny

24 Chocimska Str.

00-791 Warszawa

Tel.: + 48225421366

Fax: + 48225421307

E-Mail: achojecka@pzh.gov.pl

\section{The authors of this paper}

Dr n. biol. Agnieszka Chojecka: Specialist in the field of sterilization and disinfection processes, interested in prevention of nosocomial infection in medical area especially in methods of examination of biocidal efficiency of disinfectants. Member of Technical Committee KT 296 for Disinfection and Antiseptics of Polish Committee for Standardization.

Dr n. med. Patryk Tarka: Public health specialist. Scientific interests include epidemiology, prevention of nosocomial infections and disinfection. Author of more than 30 review articles and original themes of nosocomial infections, hand hygiene.

$\operatorname{Dr}$ n. med. Krzysztof Kanecki: Specialist in internal medicine, specialist in rheumatology. Her scientific interests include the problems of rheumatic, nosocomial infections diseases and the assessment of the quality of life dependent on health.

Dr hab. n. med. Aneta Nitsch-Osuch: Specialist pediatrician, epidemiologist specialist, public health specialist. Scientific interests include the issues of epidemiology, diagnosis, treatment and prevention of diseases important from the point of view of public health. 